\title{
Efektivitas Strategic Hope-focused Marital Enrichment untuk Peningkatan Penyesuaian Pernikahan Pasangan yang Menikah Melalui Ta'aruf
}

\section{Strategic Hope-Focused Marital Enrichment Program for Ta'aruf Couples in the Beginning Phase of Marriage}

\author{
Zulfa Febriani \\ Augustine R. Basri \\ Dini Rahma Bintari*) \\ Fakultas Psikologi, Universitas Indonesia, Depok 16424 \\ Diterima 30 Oktober 2010/Disetujui 15 November 2010
}

\begin{abstract}
Strategic hope-focused marital enrichment is on brief marital enrichment program with an eclectic approach that focused on increasing love, faith and the importance of working together as a couple to motivate couple in increasing their relationship's quality (Jakubowski, Milne, Brunner, and Miller, 2004). The program improved marital relationship, communication, marital satisfaction(Worthington Jr., Hight, Ripley, et.al, 1997) and over all quality of life (Buchard, Yarhouse, Killian, Worthington Jr, 2003). Rumondor (2010) had adopted the program on newlywed-couples that experienced dating before. This research is to test the effetivity of the program to three ta'aruf-married couples in their beginning phase of marriage. The participants attended four sessions for about a month. The quality of marital adjustment is measured by Dyadic Adjustment Scale (DAS), developed by Spanier (1976). The average total score of DAS in three couples showed an increasing on marital adjustment quality at the end of the program. The program increases dyadic consensus, dyadic satisfaction and affectional expression meanwhile does not show any difference on dyadic cohesion.
\end{abstract}

Keywords: Marital enrichment, marital adjustment, beginning phase of marriage, ta'aruf

Andrew, Whitey, Campbell, dan Converse. (Duvall \& Miller, 1985) mengatakan bahwa sebagian besar orang Amerika menganggap pernikahan dan kehidupan keluarga memberikan perasaan kepuasan hidup yang lebih besar dibandingkan aspek kehidupan lainnya. Keluarga memberikan afeksi, penerimaan, perlindungan, rasa kebermaknaan dan bertujuan dalam kehidupan, memberikan arahan sosial, dan sebagainya. Semua ini merupakan aspek penting bagi seseorang untuk dapat berkembang secara kompeten di dunia (Duvall \&. Miller, 1985).

* Korespondensi artikel ini dapat dialamatkan melalui Dini Rahma Bintari ke dini-rb@ul.acid atau HP 08131900906. 
Proses pembentukan keluarga pada umumnya dimulai melalui perkenalan di mana pasangan mencari kecocokan satu sama lain. Pasangan biasanya mengembangkan interaksi, berbagi minat dan kegiatan bersama hingga mengembangkan kelekatan fisik dan emosional. Pada masyarakat Amerika, budaya ini dikenal dengan nama dating (Bird \& Melville, 1994). Periode ini biasanya dimulai ketika mereka memasuki masa usia dewasa muda, yaitu usia 20-an hingga 30-an. Tugas perkembangan di masa ini adalah untuk menjalin suatu keintiman, mengembangkan kehidupan yang produktif dan prokreatif, bahkan menikah dan membentuk keluarga (Erikson, dalam Monte \& Sollod, 2003).

Adapun Islam memandang ikatan pernikahan sebagai mitsaqan ghalizha, yaitu perjanjian yang paling kuat di mata Allah SWT setelah akidah dan tauhid. Ketika akad nikah terjadi, segala bentuk interaksi yang tadinya merupakan dosa besar menjadi kemuliaan, dan besar sekali pahalanya di sisi Allah SWT sehingga seseorang yang telah menikah dianggap menyempumakan separuh agamanya. Nilai pernikahan sebagai ibadah dan memiliki kekuatan di mata Allah SWT menjadikan Islam membatasi tata cara pergaulan antara laki-laki dan perempuan sebelum menikah (Al-Makassari, 2007).

Islam mengatur pemilihan pasangan dengan cara yang disebut ta'aruf. Ta'aruf adalah proses mengenal dan penjajakan calon pasangan dengan bantuan dari seseorang atau lembaga yang dapat dipercaya sebagai mediator untuk menikahkan pasangan sesuai dengan kriteria yang diinginkan sebagai proses awal menuju pernikahan. Proses ini dilakukan tanpa interaksi yang intensif antara pasangan sebelum benar-benar masuk ke dalam ikatan pernikahan, cenderung berlangsung singkat dan tanpa diketahui banyak orang (Abdullah dalam Kusumastuti, 2006),

Pasangan yang baru menikah, balik yang sebelumnya berpacaran atau berta'aruf, periu melakukan penyesuaian diri agar manfaat dan tujuan pernikahan dapat dirasakan oleh pasangan serta dapat memberikan suasana pernikahan sebagaimana yang diinginkan pasangan. Penyesuaian pernikahan, menurut Spanier (1976), merupakan proses adaptasi diadik (antara dua individu) yang dapat dilihat dari dyadic consesus (derajat kesepakatan), dyadic satisfaction (kepuasan hubungan), dyadic cohesion (kedekatan hubungan), dan affectional expression (ekspresi afeksi) pada pasangan sehingga dapat dievaluasi sebagai penyesuaian pernikahan yang dianggap baik atau buruk. 
Banyak pasangan yang tidak berhasil dalam menyesuaikan diri dan membentuk keluarga yang harmonis dan langgeng. Seiring perkembangan zaman, pernikahan yang berujung kepada perceraian semakin meningkat. Di Amerika Serikat, tingkat perceraian pada tahun 2001 menurut The National Center for Health Statistics mencapai rata-rata $40 \%$ (Hurley, dalam Green, 2008). Sementara di Indonesia sendiri, sebagaimana diungkapkan Farid Ismail (Hermansyah, Mei 2010), sekretaris Badan Peradilan Agama, tahun 2009, perkara perceraian yang diputus Pengadilan Agama/Mahkamah Syariyah mencapai 223.371 perkara. Selama sembilan tahun terakhir, tiap tahun rata-rata terdapat 161.656 perceraian .

Perceraian cenderung mudah terjadi pada tahun-tahun awal pernikahan bila pasangan cepat sekali menemukan ketidakmampuan menyesuaikan peran pernikahan berdasarkan nilai, kebutuhan, dan tujuan pribadi dengan pasangan (Bird \&. Melville, 1994). Penelitian menunjukkan selama dua dekade ini konfilk pernikahan dan perceraian telah membuat pasangan dan anak-anak berada pada risiko kerugian mental, fisik, dan dampak emosional (Amato \& Keith; Emery dalam Monarch, Hartman, Whitton, \& Markman, 2002). Sebagian besar pasangan mempertahankan pernikahan, misalnya karena alasan anak, walau tidak mengalami kepuasan (Markman \& Hahlweg, dalam Monarch, Hartman, Whitton, \& Markman, 2002).

Perhatian terhadap isu tersebut mempengaruhi praktisi klinis, konselor, organisasi agama, dan pemerintah untuk mencari solusi-solusi yang memperkuat kelanggengan pernikahan (Groom, 2001). Di Amerika, pasangan biasanya mencari bantuan konselor untuk mengatasi masalah rumah tangga mereka atau membantu memperdalam hubungan mereka. Banyak relationship atau mantal-enrichment program yang bertujuan membantu pasangan mempertahankan atau meningkatkan hubungannya (Jakubowski, Milne, Brunner, \& Miller, 2004).

Program marital enrichment juga diaplikasikan sebagai usaha preventif serta bantuan untuk mengurangi distress pernikahan. Beberapa peneliti hahkan menemukan bahwa pasangan yang memiliki penyesuaian pernikahan yang awalnya buruk memiliki kecenderungan untuk mengalami perbaikan yang lebih besar setelah mengikuti program marital enrichment (Giblin, Sprenkle, Sheehan, Noval, dkk., dalam Burchard, Yarhouse, Kilian, \& Worthington, 2003).

Hawley dan Olson (Burchard, Yarhouse, Kilian, \& Worthington, 2003) mengatakan bahwa program marital enrichment memberikan keterampilan yang 
dibutuhkan pasangan untuk mengambil langkah efektif dalam situasi yang sulit serta memperkuat hubungan pernikahan. Program ini juga dapat diberikan pada pasangan yang baru menikah yang membutuhkan adaptasi dengan hubungan pernikahan dan menciptakan cara berinteraksi, berkomunikasi, dan memecahkan masalah. Krieder dan Fields (Murray \& Murray Jr., 2004) mengatakan bahwa intervensi sejak dini terhadap pasangan sangat menguntungkan karena risiko perceraian biasanya ada pada tahap awal pernikahan. Pasangan juga blasanya tidak mendapatkan pendidikan atau pelatihan formal mengenai pernikahan dan kehidupan keluarga (Hoope \& Fisher dalam Murray \& Murray Jr., 2004).

Program relationship atau marital enrichment yang telah awal berkembang antara lain Association of Couples for Marriage Enrichment (ACME) yang dilakukan dalam kelompok, mendiskusikan suatu topik permasalahan rumah tangga (Mace \& Mace, dalam Worthington, Hight, Ripley, Perrone, dkk., 1997), Relationship Enhancement (RE) yang melatih keterampilan komunikasi (Guarney dalam Worthington, Hight, Ripley, Perrone, dkk., 1997), dan lain-lain. Worthington dan koleganya (1997) mengatakan bahwa program-program tersebut belum diteliti secara empiris, berkembang pada sekitar era 1970-an yang mungkin tidak sesuai lagi dengan penemuan terkini mengenai pernikahan dan cara-cara peningkatan kualitasnya, serta membutuhkan waktu yang lama dalam pelaksanaan.

Worthington, Ripley, Hook, dan Miller (2007) mengembangkan program Strategic Hope-focused Relationship Enrichment di Amerika sejak tahun 1980-an. Pogram ini dilakukan dengan pendekatan eklektik, singkat, dan berfokus pada meningkatkan cinta kasih, keyakinan satu sama lain, dan mengusahakan bersama untuk memotivasi pasangan agar mengembangkan hubungannya. Program ini menekankan pada nilai-nilai keyakinan dan harapan (hope). Nilai ini merupakan sesuatu yang penting dalam pernikahan. Pasangan dapat memiliki hubungan yang baik biasanya karena harapan membantu mereka menghindari konflik dan mempertahankan hubungan yang membangun .

Worthington (1985) mengembangkan program tersebut berdasarkan pengalamannya melakukan praktek dalam konseling pernikahan, memberikan supervisi, ceramah atau seminar mengenai pernikahan, serta umpan balik yang ia terima dari berbagai pihak. Teknik ini terbukti efektif karena dapat dijalankan dengan cukup singkat serta menawarkan dua hal sekaligus. Pertama, program ini 
membangun keterampilan pasangan dalam berkomunikasi secara lebih baik, memecahkan perbedaan yang timbul dalam pernikahan, dan membangun komitmen untuk memperkuat hubungan. Kedua, program ini juga dapat memperbaiki masalah atau pola hubungan yang negatif yang sebelumnya mungkin pemah terjadi.

Program pengayaan pernikahan secara umum belum populer di masyarakat Indonesia. Berdasarkan pengamatan dan interaksi peneliti dengan beberapa pasangan yang sudah menikah, mereka biasanya tidak menyadari sejak awal hal-hal yang dapat berkontribusi terhadap keadaan pernikahan yang mengalami konflik atau kegagalan. Pasangan biasanya memandang suatu pernikahan baru memerlukan penanganan jika kehidupan rumah tangga mereka sudah tidak dirasakan harmonis atau banyak pemahaman dan keputusan yang tidak dapat lagi sejalan. Beberapa orang mençari solusi dengan berbicara kepada keluarga yang lebih senior, teman dekat, atau ke konsultan pernikahan. Beberapa orang lagi pergi ke lembaga peradilan agama untuk meminta nasihat pernikahan atau bahkan langsung memproses ke arah perceraian. Beberapa bahkan tetap mempertahankan keadaan pernikahan yang tidak lagi harmonis itu dengan alasan anak atau malu terhadap perceraian.

Sejauh ini belum diperoleh keterangan mengenai kelanggengan rumah tangga pasangan yang menikah melalui ta'aruf. Hendrawan (2004) berdasarkan hasil penelitiannya mengatakan bahwa pasangan yang menikah melalui ta'aruf umumnya membutuhkan penyesuaian dalam hal keterbukaan dan komunikasi dikarenakan mereka belum terlalu mengenal pasangannya. Beberapa kolega peneliti yang menikah melalui ta'aruf mengatakan bahwa masa awal pemikahan memang sangat membutuhkan kesabaran dalam menghadapi pasangan. Selain itu, mereka merasa sangat memerlukan keterbukaan dan komunikasi yang baik sehingga dapat melakukan penyesuaian yang dipertukan.

Berdasarkan keadaan di atas, maka perlu dicoba program Strategic Hopefocused Marital Enrichment pada pasangan yang baru menikah melalui ta'aruf. Program ini telah diadaptasi sebelumnya oleh Rumondor (2010) pada tiga pasangan yang baru menikah namun melalui pacaran. la menyatakan bahwa program ini cukup dapat meningkatkan kualitas penyesuaian pernikahan dua pasangan yang diteliti. Peneliti ingin melihat efektivitas program pada pasangan yang baru menikah melalui ta'aruf. 


\section{Metode Penelitian}

\section{Partisipan}

Partisipan merupakan pasangan yang telah menikah melalui proses ta'aruf, berada dalam tahun awal pernikahan dan belum memiliki anak. Partisipan dipilih secara non-random dan diambil secara accidental berdasarkan ketersediaan di lapangan. Partisipan yang diperoleh beriumlah tiga pasang. Partisipan berusia ratarata 25 tahun dan rata-rata usia pernikahan 5 bulan. Sebagian besar mereka telah bekerja sebagai karyawan dan wirausaha.

\section{Desain}

Desain penelitian ini adalah quasi-experimental dengan model one-group pretest-posttest design (tidak ada kelompok kontrol). Variabel aktif dalam penelitian ini adalah program Strategic Hope-focused Marital Enrichment. Variabel atribut adalah kualitas penyesuaian pernikahan.

\section{Intervensi}

Program Strategic Hope-Focused Marital Enrichment yang akan diberikan adalah hasil adaptasi Rumondor (2010) dari Worthington, Hight, Ripley, Perrone, dkk. (1997). Pertemuan direncanakan sebanyak 4 sesi dengan durasi sekitar 1.5 - 2 jam per sesi. Susunan intervensi akan dilakukan sebagai berikut:

1. Sesi 1: pengenalan program, visi misi pernikahan dan asesmen, keunikan pasangan (materi bahasa cinta dan memupuk cinta)

2. Sesi 2: keterampilan komunikasi \& empati

3.Sesi 3: mengatasi perbedaan

4. Sesi 4: keintiman, evaluasi program, asesmen

5. Follow-up

\section{Pengukuran}

Kualitas penyesuaian pernikahan diukur menggunakan Dyadic Adjustment Scale (DAS) dari Spanier (1976). DAS dianggap reliabel serta memiliki validitas konten, konstruk, dan kriteria yang kuat. DAS juga dianggap sebagai salah satu alat ukur yang terbaik untuk mengukur penyesuaian pemikahan (Cohen dalam Worthington, Buston, \& Hammonds, 1989). DAS telah diadaptasi sebelumnya oleh 
Mamdy (2007) pada 50 pasang suami-istri dewasa muda usia 20-35 tahun di Jakarta dan Depok. Hasil uji coba menunjukkan item-total correlation lebih dari 0.3 untuk semua butir soal dan koefisien realibilitas Alpha Cronbach sebesar 0,91. Dengan demikian DAS dapat dianggap valid dan reliabel untuk mengukur penyesuaian pernikahan pada pasangan dewasa muda. Asesmen juga dilakukan dengan wawancara mengenai penyesuaian pasangan pada masa awal pernikahannya, Selain itu, observasi interaksi pasangan selama mengikuti sesi dilakukan untuk melengkapi komponen pengukuran.

\section{Prosedur}

Peneliti menghubungi sejumlah kolega yang mengenal pasangan ta'aruf yang baru menikah sekitar satu tahun. Kolega peneliti memberikan nomor telepon caloncalon partisipan yang telah bersedia mengikuti penelitian. Peneliti menjelaskan mengenai program secara umum kepada calon partisipan melalui telepon dan meminta kesediaan pasangan untuk dapat mengikuti program selama lebih kurang satu bulan. Peneliti lalu bertemu sesuai dengan waktu yang disepakati, melakukan asesmen keadaan awal partisipan, dan melaporkan secara umum kekuatan dan potensi kualitas hubungan yang dapat ditingkatkan dengan mengikuti program. Peneliti memberikan materi yang direncanakan dan setelah program selesai, peneliti kembali melakukan asesmen. 


\section{Hasil Penelitian}

Berikut ini adalah hasil pengukuran terhadap kualitas penyesuaian pernikahan partisipan setelah mengikuti program selama satu bulan.

Tabel 1. Skor total DAS

\begin{tabular}{ccccccc}
\hline \multirow{2}{*}{$\begin{array}{c}\text { Pasangan } \\
\end{array}$} & $\begin{array}{c}\text { Suami/ } \\
\text { Istri* }\end{array}$ & $\begin{array}{c}\text { Awal } \\
\text { Program }\end{array}$ & $\begin{array}{c}\text { Akhir } \\
\text { Program }\end{array}$ & $\begin{array}{c}\% \\
\text { Perubahan }\end{array}$ & Follow & $\%$ \\
\hline \multirow{2}{*}{1} & Rowi & 135 & 140 & 3.7 & 141 & 0.7 \\
& Ami & 124 & 138 & 11.3 & 136 & -1.4 \\
& Mean & 129.5 & 139 & 7.3 & 138.5 & -0.4 \\
\hline \multirow{2}{*}{2} & Eman & 126 & 131 & 4 & 142 & 8.4 \\
& Nada & 126 & 133 & 5.5 & 140 & 5.3 \\
& Mean & 126 & 132 & 4.8 & 141 & 6.8 \\
\hline \multirow{2}{*}{3} & Anto & 134 & 133 & -0.7 & 132 & -0.7 \\
& Yani & 127 & 127 & 0 & 129 & 1.6 \\
& Mean & 130.5 & 130 & -0.4 & 130.5 & 0.4 \\
\hline
\end{tabular}

*Nama suami-istri tersebut adalah bukan nama sebenarnya. 
Tabel 2. Skor per partisipan berdasarkan dimensi DAS

Dimensi Suami Awal Akhir \% follow \% Istri* Program Program Perubahan Up Perubahan

\begin{tabular}{|c|c|c|c|c|c|c|}
\hline & Rowi & 61 & 60 & -1.6 & 61 & 1.7 \\
\hline \multirow{5}{*}{$\begin{array}{c}\text { Derajat } \\
\text { kesepakatan } \\
\text { (Dyadic } \\
\text { consensus) }\end{array}$} & Ami & 54 & 65 & 20.4 & 60 & -7.7 \\
\hline & Eman & 53 & 55 & 3.8 & 60 & 9 \\
\hline & Nada & 50 & 58 & 4- & 61 & 5.2 \\
\hline & Anto & 56 & 53 & 5.4 & 55 & 3.8 \\
\hline & Yani & 52 & 50 & -3.8 & 50 & 0 \\
\hline \multirow{6}{*}{$\begin{array}{c}\text { Derajat } \\
\text { Kepuasan } \\
\text { (Dyadic } \\
\text { satisfaction) }\end{array}$} & Rowi & 43 & 46 & 7 & 46 & 0 \\
\hline & Ami & 41 & 41 & 0 & 45 & 9.8 \\
\hline & Eman & 40 & 42 & 5 & 48 & 14.3 \\
\hline & Nada & 43 & 42 & -2.3 & 45 & 7.1 \\
\hline & Anto & 45 & 46 & 2.2 & 44 & -4.3 \\
\hline & Yani & 44 & 44 & 0 & 45 & 2.3 \\
\hline \multirow{6}{*}{$\begin{array}{l}\text { Kedekatan } \\
\text { Hubungan } \\
\text { (Dyadic } \\
\text { cohesion) }\end{array}$} & Rowi & 22 & 24 & 9 & 24 & 0 \\
\hline & Ami & 19 & 20 & 5.3 & 20 & 0 \\
\hline & Eman & 22 & 22 & 0 & 22 & 0 \\
\hline & Nada & 22 & 21 & -4.5 & 22 & 4.8 \\
\hline & Anto & 23 & 23 & 0 & 23 & 0 \\
\hline & Yani & 21 & 23 & 4.3 & 24 & 4.3 \\
\hline \multirow{6}{*}{$\begin{array}{c}\text { Ekspresi } \\
\text { Afeksi } \\
\text { (affectional } \\
\text { expression) }\end{array}$} & Rowi & 9 & 10 & 11 & 10 & 0 \\
\hline & Ami & 10 & 12 & 20 & 11 & -8.3 \\
\hline & Eman & 11 & 12 & 9 & 12 & 0 \\
\hline & Nada & 10 & 12 & 20 & 12 & 0 \\
\hline & Anto & 10 & 11 & 10 & 10 & -9 \\
\hline & Yani & 10 & 10 & 0 & 10 & 0 \\
\hline
\end{tabular}


Pada awal sesi, masing-masing pasangan menunjukkan kualitas penyesuaian pernikahan yang baik yang diindikasikan dengan skor DAS di atas 100 (Prouty, Markowski \& Barnes, 2000, dalam Mamdy, 2007). Pasca program dilakukan, setiap pasangan rata-rata menunjukkan peningkatan skor DAS antara 3-11\% kecuali pada pasangan 3 (tabel 1).

Aspek derajat kesepakatan Ami dan Eman-Nada menunjukkan peningkatan sekitar $5 \%$ ke atas pada akhir program sementara skor Rowi menunjukkan penurunan $1.6 \%$ dan skor Anto-Yani cenderung menurun sekitar $3-5 \%$ (tabel 2). Meskipun demikian, secara umum pasangan yang diteliti menunjukkan adanya peningkatan kesepakatan pasangan mengenai hal-hal seperti keluarga, rekreasi, agama, dan pembagian tugas rumah tangga pada akhir program. Pada follow-up. efek program terhadap derajat kesepakatan pada Eman-Nada cenderung mengalami peningkatan (tabel 2). Aspek derajat kesepakatan pada Ami mengalami penurunan $7.7 \%$ dari keadaan pasca program padahal Rowi cenderung meningkat $1.7 \%$ dan kembali ke keadaan awal. Aspek ini padaAnto kembali membaik saat follow up sementara pada Yani cenderung stabil (tabel 2). Bila dibandingkan dengan keadaan awal, program ini cenderung cukup meningkatkan kualitas derajat kesepakatan pasangan yang diteliti.

Aspek kepuasan hubungan ketiga pasangan rata-rata cenderung mengalami peningkatan sekitar 2-7\% pada akhir program (tabel 2). Rowi cenderung mengalami peningkatan sebesar $7 \%$ pada akhir program sementara Ami tidak mengalami perubahan (tabel 2). Pada pasangan Eman-Nada, peningkatan di akhir program hanya dialami oleh Eman sebesar $5 \%$ (tabel 2). Nada cenderung mengalami penurunan 2.3\% pada aspek kepuasan pernikahannya. Begitu pula pada pasangan Anto-Yani yang peningkatannya cenderung dialami oleh Anto sementara Yani cenderung stabil (tabel 2). Meskipun demikian, secara umum program ini memberikan peningkatan kepuasan hubungan pada pasangan bila dibandingkan dengan keadaan pasangan di awal program.

Aspek kedekatan pasangan Rowi-Ami dan Anto-Yani rata-rata cenderung mengalami peningkatan sekitar $4-9 \%$ sementara Eman-Nada rata-rata cenderung mengalami penurunan pada akhir program (tabel 2). Hal ini mengindikasikan bahwa pasangan Rowi-Ami dan Anto-Yani cenderung merasa semakin akrab setelah program berakhir yang dilihat dari peningkatan sebesar $9 \%$ pada Rowi, 5.3\% pada 
Ami, dan $4 \%$ pada Yani. Sementara itu, Eman dan Anto cenderung merasakan tidak adanya perubahan keakraban hubungan pada pernikahan mereka saat program berakhir. Nada merasa kedekatannya dengan Eman cenderung menurun diindikasikan dengan penurunan $4.3 \%$ setelah program berakhir namun tetap berada pada kualitas yang baik. Saat follow-up, efek program terhadap aspek kedekatan pasangan cenderung stabil. Berdasarkan keadaan pasangan di awal program dan saat follow-up, maka dapat dikatakan bahwa program ini cenderung memberikan kestabilan dalam aspek kedekatan pasangan yang diteliti.

Aspek ekspresi afeksi antar-pasangan rata-rata cenderung mengindikasikan peningkatan sekitar 10-20\% pada akhir program (tabel 2). Hampir setiap pasangan mengalami peningkatan skor yang mendekati skor maksimal aspek ini yaitu 12 (tabel 2). Peningkatan ini cenderung dirasakan bertahan oleh Rowi, pasangan Eman-Nada dan Yani pada saat follow-up sementara Ami dan Anto cenderung mengalami penuruan 8-9\% namun masih dalam skor yang mendekati maksimal (tabel 2). Hal ini mengindikasikan bahwa program ini dapat meningkatkan cara pasangan mengungkapkan afeksi dengan maksimal dan efeknya cenderung bertahan.

\section{Pembahasan}

\section{Temuan Utama}

Program Strategic Hope-Focused Marital Enrichment cukup efektif dalam meningkatkan kualitas penyesuaian pernikahan di masa awal pemikahan pada tiga partisipan yang menikah melalui ta'aruf. Hal ini diindikasikan dengan skor DAS yang cenderung meningkat pada akhir program dan saat follow-up. Kualitas penyesuaian pernikahan yang cenderung mengalami peningkatan adalah aspek ekspresi afeksi, derajat kesepakatan dan kepuasan hubungan sementara aspek kedekatan cenderung stabil.

Peningkatan ini juga cukup efektif karena dapat terjadi dalam waktu relatif singkat, yaitu sekitar satu bulan dengan pertemuan seminggu sekali. Pasangan yang diteliti juga cenderung menunjukkan pemahaman secara kognitif dengan kemampuan menjawab dan me-reviu materi. Mereka mampu mengikuti instruksi peneliti ketika latihan dalam sesi. Mereka juga semakin menunjukkan interaksi yang baik dengan pasangannya di depan peneliti seiring berjalannya sesi. 


\section{Efektivitas Program}

Beberapa penurunan skor DAS dapat terkait dengan keadaan ekstemal yang dialami partisipan. Pada akhir program, Ami mengatakan bahwa ia saat itu sedang dimarahi Rowi dan diberikan hukuman menghafal ayat al-Quran sebanyak beberapa lembar. Hal ini boleh jadi ada beberapa hal yang sedang tidak mereka sepakati hingga mempengaruhi derajat kesepakatan Rowi. Pasangan Eman dan Nada mengatakan bahwa mereka saat ini sedang memasuki masa jenuh dan lelah karena aktivitas Eman yang sangat sibuk. Nada juga mengakui adanya beberapa kebiasaan yang biasanya Eman lakukan namun tidak lagi ia lakukan terkait kesibukannya. Hal ini boleh jadi mempengaruhi persepsi mereka mengenai kedekatan hubungan di antara mereka.

Penurunan ini cenderung mengalami peningkatan kembali saat follow-up. Beberapa peningkatan yang telah dialami pasangan pada akhir program juga cenderung dapat bertahan ketika follow-up. Worthington (2005) mengatakan bahwa evektivitas program ini tergantung pada keadaan dan keterlibatan pasangan di luar sesi yang merupakan salah satu indikator usaha pasangan untuk meningkatkan hubungan. Pasangan Eman-Nada cenderung berpartisipasi dan cukup berusaha mengaplikasikan materi-materi program. Pasangan Rowi-Ami dan Anto-Yani cenderung kurang menyediakan kesempatan untuk mengaplikasikan materi dan mengerjakan tugas rumah. Apalagi pelaksanaan sesi 3 dan 4 pada Anto-Yani digabung menjadi sesi akhir program lalu dilakukan pengukuran. Hal ini membuat mereka tidak dapat melatih cara-cara yang telah didapat pada sesi tersebut.

Follow-up dilakukan dalam waktu seminggu setelah program berakhir. Hal ini lebih cepat d bandingkan pengukuran follow-up yang dilakukan oleh Worthington dan koleganya (1997), yaitu dua minggu setelah program berakhir. Pasangan boleh jadi belum memiliki banyak kesempatan untuk berlatih dan merasakan manfaat program. Padahal Worthington dan koleganya mengatakan bahwa follow-up sebaiknya dilakukan dengan frekuensi yang lebih lama dari dua minggu. Mereka mengatakan ada kemungkinan perbedaan hasil program yang dicapai setelah follow-up. Pengukuran efek program setelah program berakhir biasanya menunjukkan perubahan yang lebih kecil dibandingkan ketika follow-up.

Penelitian ini dilakukan untuk melihat efektivitas program pada pasangan baru menikah melalui ta'aruf dengan pre-post test one group design. Disain ini membandingkan hasil program dengan keadaan partisipan di awal program tanpa 
kelompok kontrol. Hal ini cenderung berdampak sulitnya mengetahui perubahan yang terjadi apakah benar-benar berdasarkan pemberian materi atau dilatarbelakangi oleh variabel lain. Selain itu, jumlah partisipan yang hanya tiga pasang mengakibatkan keefektivan program ini tidak dapat digeneralisasi.

Ada beberapa pertimbangan lain terkait dengan kualitas penyesuaian pemikahan. Pertama, pasangan yang diteliti memiliki usia pemikahan yang relatif muda. Mereka belum mencapai kestabilan karir dan keuangan. Berdasarkan wawancara yang dilakukan, mereka kebanyakan mengatakan sibuk untuk membagi waktu khusus berdua dan merasa memiliki tuntutan pekerjaan untuk sumber biaya penghidupan mereka, apalagi mereka semua tinggal di rumah kontrakan. Quinn dan Odell (1998) mengatakan bahwa usia, level pendidikan, dan keadaan keuangan memiliki korelasi yang positif dengan penyesuaian di tahun pertama pernikahan. Pasangan muda biasanya lebih banyak menuntut pasangannya untuk berubah sehingga membutuhkan proses penyesuaian yang besar. Sementara keadaan keuangan berkaitan dengan tingkat stres yang dapat berkontribusi terhadap kepuasan pernikahan.

Kedua, pada tahun pertama pernikahan, hambatan dan penyesuaian pernikahan juga berkaitan dengan ekspektansi dan penilaian pasangan terhadap perilaku pasangannya dan terhadap pernikahan yang mereka inginkan. Ekspektasi ini mempengaruhi penilaian pasangan terhadap kualitas penyesuaian pernikahan (Quinn \& Odell, 1998). Pasangan Rowi-Ami cenderung menganggap pernikahan mereka adalah sesuatu yang luar biasa memberikan kebaikan pada mereka meskipun mereka mengalami kesulitan karir atau berbeda cara pandang. Rowi secara jelas mengatakan bahwa la tidak terlalu ingin berinteraksi secara intensif dan memanjakan istri karena akan mengakibatkan ketergantungan emosional. la juga berpendapat bahwa komunikasi bukanlah satu-satunya hal yang dapat memperkuat pernikahan melainkan kesamaan prinsip dan komitmen. Pasangan Anto-Yani cenderung menganggap pernikahan mereka memuaskan meskipun cenderung mengalami perselisihan dan perbedaan cara mengekspresikan emosi. Mereka juga menilai segala sesuatu tidak sempurna. Mereka cenderung membatasi diri dalam memberikan nilai secara sempurna pada saat asesmen dan berjalannya program.

Ketiga, kualitas penyesuaian pernikahan juga dipengaruhi secara signifikan oleh faktor ciri kepribadian seseorang. Kecenderungan menempatkan diri pada posisi orang lain serta kemampuan mengekspresikan emosi yang baik akan 
meningkatkan dan menghadapi penyesuaian pernikahan. Kualitas penyesuaian pernikahan (King, Long \& Andrews, dalam Bouchard, Lussier, Sabourin, 1999). Hal ini boleh jadi melatarbelakangi perubahan kualitas pernikahan. Pasangan Rowi-Ami tampak saling melengkapi sifat masing-masing. Rowi terlihat mandiri, pekerja keras, dan cenderung memiliki cara pandang yang konkrit realistis, sementara Ami lebih banyak pengertian dan sabar. Pada pasangan Eman-Nada, Nada lebih cenderung emosional sementara Eman bersikap sabar dan mengalah serta berusaha membawa suasana humor dalam perbincangan mereka. Sementara pasangan AntoYani tampak sama-sama memiliki kemampuan ekspresi emosi yang perlu disesuaikan. Ciri kepribadian ini dapat berkontribusi terhadap bagaimana mereka menilai dan menghadapi penyesuaian pernikahan.

Keempat, religiusitas mempengaruhi seluruh aspek penyesuaian pernikahan kecuali pada ekspresi afeksi. Tinggi rendahnya religiusitas seseorang tidak berkaitan dengan ekspresi afeksi pada pasangannya. Keyakinan, konsekuensi, pengalaman dan ritual religi berhubungan secara positif dengan penyesuaian pernikahan (Wilson \&. Filsinger, 1998). Penelitian ini dilakukan pada pasangan yang memiliki orientasi keimanan dan keagamaan yang kuat. Mereka memiliki visi-misi pernikahan yang berorientasi pada hal-hal religi dan melakukan ritual religi yang baik setiap harinya. Mereka memilikl keyakinan dan pandangan bahwa pasangan yang mereka temukan dengan cara yang baik (ta'aruf) adalah pasangan yang terbaik untuk mereka. Hal-hal ini dapat melatarbelakangi perubahan skor DAS partisipan namun tidak diteliti.

Rumondor (2010) mengadaptasi progam ini pada pasangan yang baru menikah melalui pacaran terlebih dahulu. la mengatakan bahwa program Strategic Hope-focused Marital Enrichment cenderung tidak mengubah aspek ekspresi afeksi dan cenderung memperlihatkan penurunan pada aspek kedekatan pada pasangan yang sebelumnya berpacaran. Peneliti menemukan bahwa kualitas pernikahan suami-istri yang baru menikah melalui ta'an t tidak jauh berbeda dengan suam-istri yang sebelumnya berpacaran sebagaimana yang diindikasikan dengan skor DAS di atas 100. Program ini cenderung meningkatkan aspek ekspresi afeksi pasangan yang menikah melalui ta'aruf bahkan ke arah maksimal. Efek yang didapat bertahan ketika dilakukan follow-up. Program ini juga cenderung memberikan kestabilan pada aspek kedekatan pasangan yang menikah melalui ta'aruf. Program ini secara umum dapat meningkatkan aspek kesepakatan dan kepuasan hubungan baik pada pasangan yang menikah melalui pacaran atau ta'aruf terlebih dahulu. 
Perbedaan aspek kedekatan dan ekspresi afeksi pada suami-istri yang sebelumnya berpacaran dengan yang sebelumnya ber-ta'aruf dapat dilatarbelakangi oleh perbedaan karakteristik interaksi antara pacaran dan ta'aruf. Suami-istri yang sebelumnya berpacaran boleh jadi telah mengembangkan aspek ekspresi afeksi sehingga aspek ini cenderung stabil pada masa pernikahan. Suami-isteri yang sebelumnya ber-ta'aruf sangat membatasi ekspresi afeksi sebelum menikah sehingga aspek ini memiliki potensi berkembang yang lebih besar ketika menikah.

Suami-istri yang menikah melalui ta'aruf juga cenderung dapat mengevaluasi hubungan mereka dari segi spiritual. Mereka cenderung merasa puas dengan pernikahan mereka dan mensyukuri pasangan yang mendampingi mereka. Mereka dapat merasakan kedekatan dengan berbagi aktivitas yang mereka anggap ibadah baik dalam arti sebenarnya atau dalam arti luas, seperti saling membantu dan membuat senang pasangan.

\section{Keterbatasan dan Penelitian Lanjutan}

Program Strategic Hope-focused Marital Enrichment ini diberikan pada satu kelompok penelitian dengan jumlah partisipan tiga pasang. Hal ini menyebabkan hasil penelitian tidak dapat digeneralisasi. Hasil penelitian juga tidak dapat dipastikan secara signifikan apakah benar-benar dari hasil program atau keadaan alami partisipan.

\section{Simpulan}

\section{Simpulan dan Saran}

Pada awal program Strategic Hope-Focused Marital Enrichment tiga pasangan menunjukkan kualitas penyesuaian pernikahan yang baik yang dihasilkan oleh skor Dyadic adjusment Scale (DAS) diatas 100 , setelah pelaksanaan program setiap pasangan menunjukan peningkatan skor DAS antara $3-11 \%$, kecuali pada satu pasangan.

\section{Saran}

Penelitian lanjutan sebaiknya dilakukan pada dua kelompok penelitian. Satu sebagai kelompok kontrol dan lainnya sebagai kelompok yang menerima intervensi. Kelompok penerima intervensi juga dapat divariasikan antara pasangan yang menikah dengan ber-ta'aruf dan dengan yang berpacaran lalu dilakukan penelitian 
secara bersamaan. Penelitian juga hendaknya dilakukan dalam jumlah partisipan yang lebih besar sehingga signifikansi hasil penelitian dapat digeneralisasi secara luas dan dibentuk norma pengukuran.

Penelitian mengenal efektivitas program Strategic Hope-Focused Marital Enrichment pada kualitas penyesuaian pernikahan di masa awal pernikahan juga sebaiknya memperhatikan variabel lain yang dapat mempengaruhi efektivitas program. Penelitian berikutnya dapat menyertakan pengukuran variabel extraneous untuk mengetahui seberapa besar kontribusinya terhadap kualitas penyesuaian pernikahan pasangan, seperti pengukuran religiusitas dan ciri kepribadian pasangan khususnya dalam reaktivitas emosi. Peneliti sebaiknya melakukan follow-up setidaknya dua minggu setelah program dilakukan. Selanjutnya follow-up dilakukan lagi dalam frekuensi waktu tertentu untuk mengamati keefektivan program dalam jangka panjang. Frekuensi follow-up dapat dilakukan selama setahun atau dua tahun awal pernikahan sebelum pasangan memiliki anak sebagaimana periode ini berisiko terhadap distress pernikahan.

\section{DAFTAR PUSTAKA}

Al-Adawiyah, R. \& Syamsuddin, H. 2009. Pacaran? litih...nggak Bangefll. Surakarta: Afra Publishing.

Al-Makassari, A.a.m. 2007. ProblemaAnda: Ta'aruf Syari, Solusi Pengganti Pacaran. 15 Oktober 2010 (versi Elektronik).

Bird, G. \& Melville, K. 1994. Families And Intimate Relationships. New York: Mograwhill,inc.

Buchard, G.a., Yarhouse, M.a., Kilian, M.k., Worthington Jr, E.I. 2003. A Study Of Two Marital Enrichment Programs And Couples' Quality Of Life. Journal Of Psychology And Theology, Vol. 31, No. 3, 240-252.

Duvall, E.m. \& Miller, B.c. 1985. Marriage And Family Development (6 $6^{n}$ Ed.). New York: Harper \& Row, Publisher, Inc.

Green, E.j. 2008, April. Individuals In Conflict: An Internal Family System Approach. The Family Joumal: Counseling And Therapy For Couples And Familios, Vol. 16 No. 2, 125-131. Diambil 24 September 2010 Dari Www. sagepub.com.

Hendrawan, S. 2004. Penyesuaian Pernikahan Pada Pasangan Yang Menikah Tanpa Proses Pacaran. Fakultas Psikologi Ui Depok: Skripsi S1 Tidak Dipublikasikan. 
Hermansyah. 2010. Melonjaknya Angka Perceraian Jadi Sorotan Lagi. Diambil 6 O k t o b e r

Darihttp://www. badilag.net/index.php?option=com_content\&task $=$ view\&id $=5167$.

Jakubowski, S. F., Milne, E. P., Brunner, H., \& Miller, R. B. 2004. A Review Of Empirically Supported Marital Enrichment Programs. Family Relations, 53, 5, 528-536. Diambil 27 Oktober 2010 DariWww.proquest.com/pqdauto.

Kusumastuti, D. 2006. Kepuasan Pernikahan Pada Prla Dan Wanita Yang Menikah Melalui Proses Ta'anuf. Fakultas Psikologi UI Depok: Skripsi S1 Tidak Dipublikasikan.

Mamdy, S. Z, 2007. Penyesuaian Pernikahan Pada Pasangan Yang Baru Memiliki Anak Pertama. Fakultas Psikologi UI Depok: Tugas Akhir S2 Tidak Dipublikasikan.

Monarch, N.d., Hartman, S.g., Whitton, S.w. \& Markman, H.J. 2002. The Role Of Clinicians In The Prevention of Marital Distress And Divorce. Dalam John $\mathrm{H}$. Harvey \&Amy Wenzel (eds). A Clinician's Guide To Maintaining And Enhancing Close Relationship (pg. 233-254). New Jersey: Lawrence Erlbaum Associates, Publishers. Diambil 3 Mei 2010 Dari Wuw.gigapedia.com.

Monte, C.f. \& Sollod, R.n. 2003. Beneath The Mask: An Introduction To Theories Of Personalities $\left(7^{6}\right.$ Ed.). New Jersey: John Wiley \& Sons, Inc.

Murray, C.e. \& Murray Jr., T.I. 2004. Solution-focused Premarital Counseling: Helping Couples Build A Vision For Their Marriage. Journal Of Marital And Family Therapy, Vol. 30, No. 3, 349-358. Diambil 5 Juli 2010 Dari Wun.proquest.com/pqdauto.

Quinn, W.h. \& Odell, M. 1998. Predictors of Marital Adjustment During The First Two Years. Marriage \& Family Review, 27, 1/2, 113-130. Diambil 2 November 2010 Dari Www.proquest.com/pqdauto.

Rumondor, P.c.b. 2010. Intervensi Strategic Hope-focused Marltal Enrichment Pada Pasangan Di Masa Awal Pernikahan. Tesis. Fakultas Psikologi Ui Depok.

Spanier, G.b. 1976. Measuring Dyadic Adjustment: New Scales For Assessing The Quality Of Marriage And Similar Dyads. Joumal Of Marriage And Family, Vol. 38 , No. 1, 15-28. Diambil 27 Oktober 2010 Dari Www.jstor.org.

Wilson, M.r. \& Filsinger, E.e. Feb, 1986. Religiosity And Marital Adjustment: Multidimensional Interrelationships. Journal Of Marriage And Family, Vol. 48, No. 1, 147-151. Diambil 3 November 2010 Dari Http://wmw.jstor.org/stable/352238.

Worthington Jr., E.l., Buston, B.g. \& Hammonds, T.m. 1989. A Component Analysis Of Marriage Enrichment: Information And Treatment Modality. Joumal of 
Counseling And Development, Vol. 67, No.10, 555-560. Diambil 26 Oktober 2010 DariWww.proquest.com/padauto.

Worthington Jr., E.I., Hight, T.I. Ripley, J.s., Perrone, K.m.. Dkk. 1997. Strategic Hope-focused Relationship-enrichment Counseling With Individual Couples. Joumal Of Counseling Psychology, Vol. 44, No. 4, 381-389.

Worthington Jr., E.L. 2005. Hope-focused marriage counseling: A guide to brief therapy. Illinois: InterVersity Press.

Worthington Jr., E.L., Ripley, J.S., Hook, J.H., \& Miller, A.J. 2007. The Hope-focused aproach to couple therapy and enrichment. Joumal of Psychology and Christianity, vol. 26, No.2, 132-139. Diambil 12 Oktober 2010 dari www.proquestcom/pqdauto. 